\title{
Modal and Sandstone Composition of the Representative Turbidite from the Majalengka Sub-Basin, West Java Indonesia
}

\author{
Budi Muljana (Corresponding author) \\ Graduate School Engineering Kyushu University \\ 744 Motooka, Nishi-ku, Fukuoka 819-0395, Japan \\ Tel: 81-80-3904-0343_E-mail: budi_muljana23@yahoo.co.id \& budi-m@mine.kyushu-u.ac.jp \\ Koichiro Watanabe \\ Department of Earth Resources Engineering, Faculty of Engineering, Kyushu University \\ 744 Motooka, Nishi-ku, Fukuoka 819-0395, Japan \\ Tel: 81-80-1747-3714Ｅ-mail: wat@mine.kyushu-u.ac.jp
}

Received: January 4, 2012 Accepted: January 16, 2012 Published: March 1, 2012

doi:10.5539/jgg.v4n1p3 URL: http://dx.doi.org/10.5539/jgg.v4n1p3

\begin{abstract}
The Majalengka sub-basin is composed of an approximately $4 \mathrm{~km}$ thick turbidite-sequence subdivided into three formations as follows Cisaar, Cinambo and Cantayan Formations. The last formation is composed by two members, i.e. Halang and Bantarujeg Formations, which is distinguished by the volcanic content. All sedimentary rocks were deposited during the middle to late Miocene, where the magmatic and tectonic influences are particularly dominant. Petrography and geochemical analyses suggested that the sandstone composition was derived from multi-source sediment, which is incorporated in same strata sediment. This indicates that the tectonic event occurred actively. Most sediment-sources were derived largely from two main provinces (geological terrain) such as recycled orogen and the magmatic arc. The recycled orogen is represented by the development of thrust-fault belts, which the sediment was eroded from uplifting the paleohigh. On the other side, the magmatic arc corresponded to the Southern Mountains, as a product of the early subduction in Java during the Oligocene. According to geochemical data, this indicates that there is no evidence supporting from the sediment source derived directly from the continental terrain. The quartz content is interpreted as occurring from resedimentation processes of previous sediment. Meanwhile, lithic fragment are dominantly composed by andesitic grains, which indicates that the magmatic terrain as a sediment source relates to subduction processes.
\end{abstract}

Keywords: The Majalengka sub-basin, Turbidite, Thrust-fault belts, The Southern Mountain

\section{Introduction}

The Majalengka sub-basin at West Java Indonesia, containing more than $4 \mathrm{~km}$ of turbidites, is located in the eastern part of the Bogor trough (Martodjojo, 1984). This basin is situated between the Northwest Java basin to the north and the Southern Mountain to the south. During the middle to late Miocene, both geological provenances have a role important for sedimentation in this basin. The distribution of oil-seeps and the successful first well-exploration in 1871 by two Dutch encouraged this area to be seen as yielding economic value for hydrocarbon accumulation. The major constraints are the high volcanic content and the tectonic complication. However, the investigation to identify new exploration targets has to be done. Figure 1 show the geology map and study area.

The primary stage for hydrocarbon exploration in a region is a reconstruction of paleogeography and the tectonic history. These events are created according to the plate tectonic concept and it could be arranged by using analysis of sandstone composition. The relationship between this concept and sandstone petrography and geochemistry have been studied by many researchers (e.g. Dickinson and Suczek, 1979; Ingersoll and Suczek, 1979; Dickinson, 1985). Determining sandstone composition is an effective tool for provenance, the study of tectonic and magmatic events (Dickinson and Suczek, 1979; Dickinson, 1985; Kumon and Kiminami, 1994). This method is even more powerful when combined with paleobathymetry and paleocurrent analysis. 
Related to provenance study in the Majalengka sub-basin, Martodjojo (1984) concluded that the sediments-source were derived from the Southern Mountain in the south. Meanwhile, Satyana and Armadita (2004) mentioned that the north and south the regions were the source of sediment, while Clement et al. (2009) pointed out the sediment source was derived from two regions, west and north, and there are no indication from the south. Another researcher (Muljana, 2006; Muljana et al., 2011) concluded that the sediment sources in this basin were derived from multi-source regions and represents re-sedimentation deposits.

The purpose of this paper is to describe and interpret the turbidite sequence from the Majalengka sub-basin in relation to provenance and sediment composition deposited during the middle to late Miocene. Furthermore, the tectonic setting and depositional period related to magmatic events is also decided during this time span. Currently, the present contribution will analyze the sandstone composition to ensure the tectonic setting related to magmatic processes of the Majalengka sub-basin and to resolve whether or not any important change occurred.

\section{Geological Framework}

Van Bemmelen (1949) divided the West Java into four physiographic units: (a) the Coastal Plain of Jakarta (b) the Bogor zone (c) the Bandung zone and (d) the Southern Mountain. Each zone reflects the regional structures and stratigraphy of West Java and the short-explanation is resumed below.

The Coastal Plain of Jakarta extends west to east. The plain is represented of onshore part of the Northwest Java basin (Patmosukismo and Yahya, 1974). The Tertiary sedimentary rock in this region is gently folded and covered by alluvial and lahar from Quaternary volcanic. This area is one of the prolific zones for hydrocarbon accumulation in West Java.

The Bandung and Bogor zone is situated in the interior of West Java. Both represent the shelf edge and the deepest part of the Bogor trough, respectively. In the Bandung zone, the Tertiary sediment, a stratum is mostly covered by Quaternary volcanic, alluvial, and lake deposits.

The Bogor trough is filled by Tertiary turbidite, which is tightly folded and thrusted northward onto the shelf sediments (Koesoemadinata and Martodjojo, 1974; Martodjojo, 1984). Meanwhile, the study area is located at western part of the Bogor trough and called as the Majalengka sub-basin. This basin is arranged turbidite sequence in the lower part (Cisaar, Cinambo and Cantayan Formation), while in the upper is more generated transgressive deposits (Subang and Kaliwangu Formations) (Djuhaeni and Martodjojo, 1989). The objective study is turbidite sequence. In figure 2 shows the lithologic log of the study area.

The next zone is the Southern Mountain composed of Jampang Formation, a succession of breccias and volcanogenic sandstones in andesite composition. This zone forms volcanic hills in the southern part of West Java extending west to east (Martodjojo, 1984). This series was formed during the Oligo-Miocene magmatism related to subduction process in West Java and regarded as the first magmatic activity. Sediment sources in Majalengka sub-basin, which dominated by lithic volcanic, were derived from this area.

\subsection{Majalengka Sub-Basin}

Regionally, the Majalengka sub-basin is bounded by two geologic terrains, the northwest Java basin in the north and the southern mountain in the south. Both take effect to sedimentary rock compositions.

Lithostratigraphically, the sedimentary rock units in Majalengka sub-basin can be divided into three formations, from bottom to top, i.e. Cisaar, Cinambo and Cantayan Formations. According to biostratigraphy analysis, the turbidite can be divided into two portions, lower and upper parts. The lower part consists of two lithologic units, Cisaar and Cinambo Formations, while the upper part is arranged by one lithologic unit, Cantayan Formation. The upper-part formation consisted of two members, Halang and Bantarujeg, which are both high volcanic fragment and matrix contents. The turbidite in Majalengka sub-basin consists of dominantly sandstone intercalation with shale. These sediments are deposited in shallow to deep marine environment during the middle to late Miocene. Slope deposit in channel system is paleogeography formed during this time. Deformation complex and high volcanic influx are two main geologic events, which influenced the deposition process.

\section{Methodology}

Provenance and sandstone geochemistry samples were obtained from all intervals of turbidite-sequence. Ninety-eight of fresh samples were selected for petrography study. This study was conducted to determinate rock type and provenance analysis (Petijhon et al., 1972; Dickinson and Suczek, 1979). The provenance was determined using modal analyses, according to the classification of Dickinson and Suczek (1979). This analysis was performed on 300 points, the Gazzi- Dickinson methods to characterize the provenance source and tectonic setting (Ingersoll et al., 1984; Zuffa, 1985). 
X-ray fluorescence (XRF) analysis for major and trace element geochemistry of thirty-four samples was conducted at Economic Geology laboratory, Kyushu University, Japan. Bulk chemical composition of sedimentary rock were analyzed using a Rigaku RIX 3100 X-ray (50 kv $80 \mathrm{~mA}$ ) Fluorescence (XRF) machine. Pressed-powder pellets, which $10 \mathrm{~mm}$ diameter to determine of sediment composition, were prepared. Loss on ignition (LOI) was determined by evaporating the $\mathrm{H}_{2} \mathrm{O}$ content at $105^{\circ} \mathrm{C}$ for 1.5 hours and then followed by heating to reach $500^{\circ} \mathrm{C}$ during half hours and $950^{\circ} \mathrm{C}$ for 1 hour. The LOI value, the percentage loss in sample weight less the $\mathrm{H}_{2} \mathrm{O}$ less, was calculated.

\section{Results}

The explanation of modal analysis and geochemistry of turbidites-sequence in Majalengka sub basin was focused on two aspects i.e. the process of magmatism and tectonism. Those aspects have an important role determining the provenance source in this basin.

\subsection{Petrography of Sediments}

The framework grains of the sandstone on the Majalengka sub-basin include quartz, feldspar and lithic fragment. The sandstone is a part of the turbidite-sequence. By studying the texture of this sedimentary rock, most of them are composed by very-fine to fine grain size, and coarser ones occasionally are found rounded to broken rounded. The grain course normally occupied the bottom side or floating in middle part of the rock. This sedimentary rock was moved by a high-energy environment and through short-distance transport. The sedimentation process was also creating the high content of matrix in very fine to clay size. Moreover, these processes produced the well-sorted of the grain size, but sometime also break to fine-grained to be the source of angular grains, which results in a decrease of the sediment sorting. Three main grains within sandstone samples were arranged with quartz, feldspar and lithic fragment. They were distributed in vary quantities in throughout samples interval. In addition to three detritus units above, the matrix was found to be dominated by in very fine sand to clay. In figure 3 shows the representative of sandstone in photomicrograph scale.

\subsubsection{Quartz}

Quartz, based upon thin section examination, was commonly found as quartz- monocrystaline (Qm) and quartz-polycrystaline $(\mathrm{Qp})$. The quartz-monocrytalline was characterized by rounded to sub-angular grains and was only found in one variant. This variant was characterized by a smooth undulating surface. Quartz-polycrystalline was mainly composed by two sub-grains, in which irregular sutured was contact intergranular. This revealed that the crystalline type was derived from volcanic-origins. Both of the quartz-crystalline did not identify a presence of inclusion in the surface of mineral, it indicates that quartz-crystalline was not directly derived from a volcanic-source, but as resedimentation of previous rock. Meanwhile, the $\mathrm{Qm} / \mathrm{Qp}$ ratio, in stratigraphic intervals toward to upper part, indicates the depletion value, in which well correlate with a decrease in grain size (Dickinson, 1971). High lithic fragment which dominated by quartz-polycrystaline $(\mathrm{Qp})$ was usually indicated by fine grain.

\subsubsection{Feldspar}

Common feldspar minerals consisted of Plagioclase-feldspar (P) and Alkali-feldspar (K). Throughout the samples, there was a tendency of increasing plagioclase compared to feldspar. Plagioclase grains were mainly medium form, and dominated by euhedral to subhedral in shape. Albite-twinning texture was commonly found. Some of samples show zoning, indicating it was likely derived from a volcanic source. In size, K-feldspar was much smaller than plagioclase. In the surface process, most of the feldspar minerals were unstable minerals creating microcrystalline clay minerals even though some of them were found fresh and unaltered. The microcrystalline clay minerals were fills in cleavage planes and on the surfaces of the feldspars. This process was due to alteration effect in sandstone.

\subsubsection{Lithic Fragment}

Similar with feldspar, lithic fragments in sedimentary environment were generally considered as unstable. Throughout the samples the lithic fragments were composed of three types, namely volcanic-rock, sedimentary-rock, and a small portion of metamorphic rock fragments. The volcanic fragments were much less abundant than two other types of fragmentation. Andesitic to basaltic grains was the main composition of this rock-fragment, and evenly distributed. The average grain-size was characterized as medium to coarse grains, and the shape average was angular to sub-angular. Common fragments, which belong to sedimentary rock, consist of shale, fine sand and coal fragments and occasionally the carbonate grain is found. The occurrence of shale fragments coinciding with coal fragments was rare in sedimentary rock due to their mechanical weakness during transportation processes. Hence, this preservation in sedimentary rock indicates that it was likely a short-distance 
from the source. Muscovite was considered as metamorphic rock fragment. In the wacke-sandstone (matrix content $\geq 15 \%$ ), high lithic fragment content was common.

\subsubsection{Matrix}

The matrix in sedimentary rock was commonly the finer grained mass to embed the larger grains, or clasts. The average matrix size throughout samples was very fine-sand to clay, and normally distributed in pore-spaces or as clay rims surrounding the grains. According to field investigation at outcrops, it can be determined that the composition between matrix and grains was identical. It was concluded that the sediment was derived from intra-formational or intra-basin source.

\subsection{Modal Analysis}

Systematic petrography analysis of the turbidite in Majalengka sub-basin has carried out by using modal analysis. Full grain populations with different purposes in QFL triangular diagram presented by some previous researcher (Dickinson, 1971, Dickinson and Suczek, 1979; and Kumon and Kiminami, 1994) were conducted to determine provenance, magmatic evolution, and tectonic setting (Figure 4). Furthermore, to describe grain size variation in source rocks related to tectonism, the same researcher suggested the used of QmFLt triangular diagrams. Ingersoll and Suczek, (1979) utilized lithic fragments as part of grain population to determine provenance and basin type (Figure 5a). It could show the character of polycrystalline and monocrystalline in the framework. Further the QpLvLs and LmLvLs triangular diagrams were used (Figure 5b).

This QFL triangular diagram (after Dickinson, 1971) was divided into three groups i.e. A, B, and C. A to C groups represented the increase of plagioclase $(\mathrm{P})$ and lithic volcanic $(\mathrm{V})$, but on the other side the depletion value of feldspar (F) and total unstable rock fragment (L) occurred. Plotting data on this diagram demonstrated that the lower part belongs to $\mathrm{B}(\mathrm{P} / \mathrm{F}=0.75-1$ and $\mathrm{V} / \mathrm{L}=0.5-1)$, whereas the upper part belongs to $\mathrm{A}(\mathrm{P} / \mathrm{F}$ and $\mathrm{V} / \mathrm{L}$ ratio nearby 1$)$. The increasing ratio indicated that the enhancement of a volcanic origin occurred. It was shown normally by dominance of volcanic fragment accompanied by an increase of plagioclase. The samples populations in the QFL triangular diagram (after Dickinson and Suczek, 1979) was distributed in three fields i.e. magmatism arc dominated, recycled orogen and basement uplifted. On the magmatic arc field, the sample population led to lithic fragment trends to move to the transition fields. In the recycled orogens, shifted populations moved from recycled to lithic recycled as an indicator for reactivation of thrust fault belts. The basement uplifted sample population showed the sediment exhibited the same source and was probably derived from a plutonic origin. The different interpretation for focusing on magmatic evolution is shown by QFL triangular diagram presented by Kumon and Kiminami (1994). They divided magmatism provenances into four categories i.e. (1) primitive volcanic arc provenance (PVA), (2) evolved and mature magmatic arc (EMA), (3) dissected magmatic arc (DMA), and (4) renewed magmatic arc (RMA). In this triangular diagram, the lower part samples indicates there was slight fall in dissected magmatic arc provenance (DMA) to evolved and matured magmatic arc provenance fields (EMA), and a small portion lies on primitive volcanic arc provenance (PVA). The contrast result was obtained from the upper part samples, most populations were distributed in evolved and maturated magmatic arc provenance (EMA) and primitive volcanic arc provenance (PVA). Individually samples were distributed in dissected magmatic arc provenance (DMA) and renewed magmatic arc provenance (RMA). From lower to upper, the sample population tends to show renewed of magmatic evolution during the middle to late Miocene.

Similar results was shown by QmFL triangular diagram after Dickinson and Suczek (1979), whereas the sample population in the magmatic arc appeared as if moving from dissected to transitional in the lower part and continue to un-dissected magmatism arc fields in the upper part. Theoretically, magmatic generation in the island arc system was normally moving from un-dissected to transitional (Kumon and Kiminami, 1994). Eventually, the maturation stages of the magmatic arc generation were not achieved and the new island arc system commenced. Furthermore, plotting on QpLvLs and LmLvLs triangular diagrams (Ingersoll and Suczek, 1979) indicated that the sample population fall in the mixed magmatic arc and rifted continental margin fields, a tectonic setting which normally forms within a back-arc basin. The back-arc basin normally obtains the sediment source from a magmatic-arc and craton area.

\subsection{Modal Composition}

The mean value of three main detrital in samples demonstrated a vary composition stratigraphically (Table 1). But the lithic fragments dominated some volcanic source were found very abundantly and tend to increase towards the upper part.

The other fragment found in little amount but good indication for sedimentary process is coal, mud, and carbonate fragments. Coal was deposited in a transition zone, formed normally in the deltaic to fluvial environments. Mud or shale was deposited in wide-range environment, from terrestrial to deep marine 
environment. The occurrence of fragment-imbrication in the bottom side of sandstone indicated that the sandstone was deposited by a strong current. Related to a deep marine environment, this sedimentary structure was a type for channel systems. The other fragment was carbonate rock as is typical for shallow marine deposits in a quiet condition and was indicated by free siliciclastic supply. Erosion of positive morphology in shallow marine was responsible for the presence of these fragments. The occurrence of transition to shallow marine fragments (coal and limestone detritus) indicated that sedimentation transportation occurred in short distance.

\subsection{Geochemistry of Sandstone}

Geochemical composition of sandstone in Majalengka sub-basin showed variation from bottom to top (Table 2). The depletion value of $\mathrm{SiO}_{2}, \mathrm{Al}_{2} \mathrm{O}_{3}$ and $\mathrm{FeO}$ and $\mathrm{MgO}$ are indicators for mafic rocks and are followed by the restoration of $\mathrm{TiO}_{2}, \mathrm{MnO}, \mathrm{CaO}, \mathrm{K}_{2} \mathrm{O}$ and $\mathrm{P}_{2} \mathrm{O}_{5}$. Even though several major elemental indicators for mafic rocks underwent a decrease value, this was less than felsic rock. Therefore, the rock composition relatively tended to become mafic rock as the source from a volcanic-origin.

Pettijhon et al. (1972) proposed petrofacies classification by using $\log \left(\mathrm{SiO}_{2} / \mathrm{Al}_{2} \mathrm{O}_{3}\right)$ to $\log \left(\mathrm{Na}_{2} \mathrm{O} / \mathrm{K}_{2} \mathrm{O}\right)$ ratio. In this diagram, there were six petrofacies types identified (e.g. greywacke, litharenite, arkose, subarkose, sublitharenite, and quartzarenite). The sample population plotted exclusively in the greywacke field, but shifted a little towards to litharenite in the upper part. Sandstone greywacke was composed of a mixture of quartz, feldspar and lithic fragment bounded by matrix composition approximately clay to silt-size and consisted of more or less over $15 \%$. Matrix in the sandstone greywacke could play a role as a transport medium. Hence, this sandstone type was a good guide for provenance and tectonic setting discrimination compared as climate indicator (Figure 6a).

Meanwhile, lithareneite was a sandstone type dominated by lithic fragment, very low of matrix, a good indicator for local provenance and short distance transportation. The fragment was derived from uplifted and unroffing of some part of sedimentary basin. Geochemically, this sandstone was characterized by high $\mathrm{Al}_{2} \mathrm{O}_{3}$ but low $\mathrm{Na}_{2} \mathrm{O}$ and $\mathrm{MgO}$ values. Therefore, both of the sandstone types could be classified as immature sandstones, deposited through turbidite process in a marine environment.

According to the petrofacies classification, the $\mathrm{SiO}_{2} / \mathrm{Al}_{2} \mathrm{O}_{3}$ ratio represented comparison between quartz and aluminiun-silicates which one representative of the matrix content. Meanwhile, the $\mathrm{Na}_{2} \mathrm{O} / \mathrm{K}_{2} \mathrm{O}$ ratio demonstrated a compared value of plagioclase-feldspar and $\mathrm{K}$-feldspar. On this diagram, the population samples had a tendency toward a constant $\mathrm{SiO}_{2} / \mathrm{Al}_{2} \mathrm{O}_{3}$ ratio, but $\mathrm{Na}_{2} \mathrm{O} / \mathrm{K}_{2} \mathrm{O}$ ratio tended to decline.

$\mathrm{TiO}_{2}$ vs. Ni diagram (Floyd et al., 1989) indicate that the all samples from lower to upper mostly located at the same area (Figure 6b). Acid volcanic fragment and some sedimentary rocks such as sandstone and mudstone is a common lithic fragment in this sediment.

To determine tectonic setting based on greywacke composition was proposed by Crook (1974). Average of $\mathrm{SiO}_{2}$ and $\mathrm{K}_{2} \mathrm{O} / \mathrm{Na}_{2} \mathrm{O}$ ratio was used as parameters for classification. Furthermore, the classification was divided into three categories (1) quartz-poor greywacke (average $58 \% \mathrm{SiO}_{2}, \mathrm{~K}_{2} \mathrm{O} / \mathrm{Na}_{2} \mathrm{O}<<1$ ) as an indicative of magmatism in the island arcs and that of tholeiitic-calc alkaline (2) quartz-intermediate greywacke (average $68-74 \%$, $\mathrm{K}_{2} \mathrm{O} / \mathrm{Na}_{2} \mathrm{O}<1$ ) as indicators of Andean type continental margin (3) quartz-rich greywacke indicated Atlantic-type continental margin. On this classification the sample population belongs to quartz-poor greywacke with a composition of $67-55.5 \%$ and $\mathrm{K}_{2} \mathrm{O} / \mathrm{Na}_{2} \mathrm{O}$ ratio below 1 or including first category Magmatism island arc. The magmatism arc provenance was considered responsible for sediment origin which was dominantly composed of dacite to andesite (Figure 6c).

Related to magmatic arc as a provenance source, Kumon and Kiminami (1994) proposed the use of the ratio between $\left(\mathrm{Al}_{2} \mathrm{O}_{3} / \mathrm{SiO}_{2}\right)$ vs. $(\mathrm{FeO}+\mathrm{MgO}) /\left(\mathrm{SiO}_{2}+\mathrm{K}_{2} \mathrm{O}+\mathrm{Na}_{2} \mathrm{O}\right)$. The $\mathrm{Al}_{2} \mathrm{O}_{3} / \mathrm{SiO}_{2}$ ratio corresponded with comparison between feldspar to quartz as a representation of maturity level of the rocks. Meanwhile, ( $\mathrm{FeO}+\mathrm{MgO}) /$ $\left(\mathrm{SiO}_{2}+\mathrm{K}_{2} \mathrm{O}+\mathrm{Na}_{2} \mathrm{O}\right)$ ratio shown a basicity index or B.I index, whereas the $\mathrm{FeO}+\mathrm{MgO}$ represented mafic rocks and $\mathrm{SiO}_{2}+\mathrm{K}_{2} \mathrm{O}+\mathrm{Na}_{2} \mathrm{O}$ represented felsic rocks (Figure 6d). The general evolution of the magmatism arc was occurred from oceanic island arc (immature island arc) to continental island arc (mature island arc).

On this diagram, the sample population in the lower part plotted in two fields (1) oceanic island arc, and (2) continental island arc, whereas in the upper part all samples were concentrated on oceanic island arc. This is case indicating that the iteration of subduction process occurred.

A distinctive mineralogical and geochemical signature in sedimentary rocks reflects tectonic process in plate tectonic concept. Based on this concept, the sedimentary basin could be determined. Several workers (e.g. Bhatia, 1983; Roser and Korch, 1986) have used the geochemistry of sandstone composition to determine the tectonic setting related to sedimentary basins (Figure 7a). Bhatia (1983) has divided into four types based on maturation 
level of island arc which were oceanic island arcs (ARC), continental island arcs, active continental margins (ACM) and passive margins (PM). Plotting samples using discriminant function (Bhatia, 1983) indicated that the sample population in the lower part was situated on oceanic island arc (ARC)-continental island arc- active continental margin (ACM), whereas the sample population in the upper part falls in only two types i.e. oceanic island arc (ARC) and active continental margin (ACM). The absence of origin samples from active continental margin (ACM) in this interval indicated that re-activation of oceanic influence had occurred (Figure 7b). On the other side, Roser and Korch (1986) separated the tectonic setting based on $\mathrm{K}_{2} \mathrm{O} / \mathrm{Na}_{2} \mathrm{O}-\mathrm{SiO}_{2}$ ratio in three types i.e. oceanic island arc (ARC), active continental margin ( $\mathrm{ACM}$ ) and passive margin (PM). Plotting data on $\mathrm{K}_{2} \mathrm{O} / \mathrm{Na}_{2} \mathrm{O}-\mathrm{SiO}_{2}$ ratio (Roser and Korch, 1986), in both intervals, were lies on oceanic island arc (ARC) and active continental margin (ACM). The increase of $\mathrm{K}_{2} \mathrm{O} / \mathrm{Na}_{2} \mathrm{O}$ ratio followed a decrease of $\mathrm{SiO}_{2}$ value on the upper part indicates that the tectonic setting led to younger stages. Most importantly, both diagrams, demonstrated that there were no indication the sediment source from passive margin or stable areas.

\section{Discussion}

The petrography and geochemical study of turbidite series in Majalengka sub-basin has shown that the sedimentary rocks were composed of greywacke and litharenite. In relation to provenance, these sedimentary rocks provide good guides for mixed sedimentary and volcanic terrain sources. Most of them are relatively deposited in local-source, perhaps within uplifted sedimentary strata or plutonic bodies. It is normally created in the same sedimentary basin as an intra-fragment and deposited as resedimentation process.

A common characteristic of this sediment was arranged by three main detritus (quartz, feldspar and lithic fragments) and matrixes, the matrix content become reduced from greywacke towards litharenite. This reflects that the maturity levels were declining and the sedimentary rock belongs to immature rocks. Furthermore, the immaturity circumstance was manifested in the abundance of lithic fragments, $\mathrm{K}_{2} \mathrm{O} / \mathrm{Na}_{2} \mathrm{O}$ ratio $<<1$ and low $\mathrm{Na}_{2} \mathrm{O}$ and $\mathrm{SiO}_{2}$ values. Poor-quartz indicates that the lithic fragment was composed dominantly from a volcanic origin.

Re-sedimentation, local provenance, and immature rocks are sedimentary aspects describing short-distance of sedimentation process. In particular an increase in monocrystalline quartz contents in the lower part was probably derived from plutonic bodies. Modal analysis and geochemical data show no indication that the sediment source was derived directly from passive margins or craton terrain. Sediment source from the Northwest Java basin was not directly deposited in the Majalengka sub-basin.

Moving and uplifting of thrust-fold belts in the late Miocene are considered as one of the factors for the increase of lithic fragments aside from the magmatism arc. Thin-skin deformation due to the compression regime describes the tectonic feature acting at this time.

These turbidites sequence were deposited on the back-arc basin (Majalengka sub-basin) as a sedimentary basin created during the middle to late Miocene (Muljana and Noeradi, 2009; Muljana and Watanabe, 2010; Muljana et.al., 2011). This basin was flanked by two main geological provinces, the Northwest Java Basin in the north and Southern Mountains in the south. The Northwest Java Basin was dominated by quartz-rich but poor volcanic fragments, whereas the Southern Mountain was vice versa. Therefore, it will give the different contribution of sedimentary source at Majalengka sub-basin.

Modal analysis and geochemical interpretation indicate that the basin was located on an active zone (i.e. island arc system). Mixing by several tectonic settings, besides sediment source, denote a crust composition probably composed by transition crustal. Gage and Wing (1980) suggested that the crust beneath the entire Northwest Java Basin continues to the south of West Java relatively thin indicating it was probably transitional between oceanic and continental crusts.

Based on petrography and geochemical interpretations this indicates that magmatic and tectonic activities have renewed generation. The volcanism paucity and re-subduction are two events during that time. This was supported by K-Ar dating analysis on several Tertiary volcanic rocks in Java Island, which is conducted by Soeria-Atmadja et.al. (1994). The results of this study suggest that there are two magmatism periods in Java during the Tertiary. Each period creates the magmatism belt parallel to Java Island. Figure 8 shows the cartoon of the basin forming during the middle to late Miocene.

The first period took place at $40 \mathrm{Ma}$ to $19-18 \mathrm{Ma}$ (Oligo-Miocene) located along the southern part of Java island. Meanwhile, the second period occurred at 12 or $11 \mathrm{Ma}$ to $2 \mathrm{Ma}$ (Plio-Pliestocene), lying relatively superimposed with the recent volcanism. The relative paucity of magmatism around $18 \mathrm{Ma}$ to $12 \mathrm{Ma}$ was interpreted due to the decreasing velocity of plate motion in southern Java as an implication of subduction in South Sulawesi. It yields the distinctive composition of volcanic rock products, tholeiitic series (first periods) becomes tholeiitic-calc alkaline (second period). Plotting data on triangular diagrams $\mathrm{CaO}-\mathrm{Na}_{2} \mathrm{O}-\mathrm{K}_{2} \mathrm{O}$ after Le Maitre (1976) indicates 
that the sediment source was derived from tholeiitic series composition. Meantime, the turbidite-sequence in Majalengka sub-basin was deposited during the middle to late Miocene or approximately $15 \mathrm{Ma}$ to $5 \mathrm{Ma}$.

\section{Conclusion}

Turbidite in the Majalengka sub-basin is derived from the multi-source terrains. Two main geologic provinces such as the Northwest Java Basin in the north and the Southern Mountain in the south are considered to have a role important for the sediment origin. The sediment was deposited in the short-distance. Provenance study indicated that during the sedimentation processes, from the middle to late Miocene, the changing of the sedimentation direction occurred. During the middle Miocene, the sediment source was derived mainly from two-part regions of tectonic setting, the recycled orogen and magmatic arc. Within the recycled orogen, the sediment source is normally derived from sedimentary strata and sub-ordinate volcanic rocks. They exposed due to erosion by the orogenic uplifting of fold belts and thrust sheets. There are no indications that sediment was derived from the continental terrain, or sediment was deposited directly from the north. However, it resulted by transportation sediment as a resedimentation process or erosional of paleohigh of the basement uplifts. Furthermore, entering to the late Miocene, the sediment volcanic from the south was deposited dominantly. The Southern Mountain, as a product of the early subduction in the Java Island is considered responsible for the sediment fountain in this area. High andesitic content indicates that the magmatic event related to subduction process. The stratigraphic increase in the volcanic input makes clear as a result the unroofing of the andesite magmatic terrain.

\section{Acknowledgments}

The first author would like to thank the Ministry of National Education of the Republic Indonesia for my scholarships, Global-Centre of Excellence (G-COE) in Novel Carbon Resource Science, Kyushu University, Japan for fieldworks fund supported, and Faculty of Geology, Padjadjaran University, Indonesia. And also he would like to greatly thank Dr. Darjie Noeradi from The Bandung Institute of Technology (ITB) and Mega Fatima Rosana, Ph. D, Djadjang Djedi Setiadi, M. Sc. and Cipta Endyana, ST., MT, from Faculty of Geology, Padjadjaran University, Indonesia. Authors would like to thank Mr. Thomas Tindell David for editing and commenting on the English Grammar.

\section{References}

Bhatia, M. R. (1983). Plate tectonisms and geochemical composition of sandstones. Journal Geology, 91, 611-627. http://dx.doi.org/10.1086/628815

Clements, B., Hall. R, Smyth, H. R. \& Cottam. M. A. (2009). Thrusting of a volcanic arc: a new structural model for Java. Petroleum Geoscience, 15(2), 159-174. http://pg.geoscienceworld.org/content/15/2/159

Crook, K. A. W. (1974). Lithogenesis and geotectonisms: the significance of compositional variation in flysch arenits (greywackes). Soc. Econ. Paleontol. Mineral, Spec. Pub. 19. 304-310.

Dickinson, W. R. (1971). Clastic sedimentary sequences deposited in shelf, slope, and trough settings between magmatism arcs and associated trenches. Pasific Geology, 3, 15-30.

Dickinson, W. R. (1985). Interpreting detrital modes of greywacke and arkose. Journal Sediment Petrology, 40, 695-707. http://jsedres.sepmonline.org/content/40/2/695.full.pdf

Dickinson, W. R., \& Suczek, C. A. (1979). Plate tectonisms and sandstone compositions. Am. Assoc. Petrol. Geol. Bull, 63, 2-31.

Djuhaeni \& Martodjojo. (1989). Stratigraphy of Majalengka area and relationships with nomenclature of lithostratigraphy units in Bogor basin. Geologi Indonesia, 12 (1), 227-252. http://jsedres.geoscienceworld.org/content/54/1/103.

Floyd, J. A., Winchester \& Park, R. G. (1989). Geochemistry and tectonism setting of Lewisian clastic metasediments from the Early Proterozoic Loch Maree Group of Gairloch, N.W. Scotland. Precambrian Res, 45, 203-214. http://dx.doi.org/10.1016/0301-9268(89)90040-5

Gage, M. S. \& Wing, R. S. (1980). Southeast Asia. Basin types versus opportunities. Proc. IPA. ${ }^{\text {th }}$ Ann.Conv. 123-148. http://www.muststayawake.com/SDAG/library/ESS/Dickinson_Suczek1979.pdf

Ingersoll, R. V., \& Suczek, C. A. (1979). Petrology and Provenance of Neogen sand from Nicobar and Bengal fans, DSDP sites 211 and 218. Journal Sedimentology Petrology, 49, 1217-1228. http://jsedres.sepmonline.org/content/49/4/1217.

Ingersoll, R. V., Bullard, T. F. \& Ford, R. L. (1984). The effect of grain size on detrital modes: A test of the Gazzi-Dickinson point-counting method. Journal of Sediment Petrology, 54, 103-116. 
Kumon, F. \& Kiminami, K. (1994). In: Sandstone Petrology in relation to tectonism (edits.), Modal and chemical compositions of the representative sandstone from Japanese Islands and their tectonism implications. ( Proceedings of the $29^{\text {th }}$ International Congress part. A., p. 135-151). The Netherlands: VSP BV.

Koesoemadinata, R. P. \& Martodjojo, S. (1974). Penelitian Turbidit di Pulau Jawa. Annual report geology, 1295/74, 12-24.

Le Maitre, R. W. (1976). The Chemical variability of some Common Igneous Rocks. Journal of Petrology, 17(4), 589-598. http://petrology.oxfordjournals.org/content/17/4/589

Martodjojo, S. (1984). Bogor basin evaluation, West Java (Evolusi Cekungan Bogor, Jawa Barat), Doctorate thesis, ITB. Bandung, Indonesia: Institut Teknologi Bandung press.

Muljana, B. \& Noeradi, D. (2009). Provenance of Volcanogenic Turbidite in Majalengka West Java, Indonesia. International Symposium on Earth and Technology, Kyushu University Japan. 253-258.

Muljana, B. \& Watanabe, K. (2010). Sandstone Composition and Provenance of the Cinambo and Halang Formations in Majalengka West Java, Indonesia. International Symposium on Earth and Technology, Kyushu University Japan. 427-428.

Muljana, B., Watanabe, K. \& Rosana, M. F. (2011). Sandstone composition of the Turbidite series in middle to late Miocene of Majalengka sub-basin, West Java Indonesia. Indonesia. International Symposium on Earth and Technology, Kyushu University Japan. 427-428.

Muljana, B. (2006). Geometri dan Facies turbidit Majalengka. Jawa Barat, Master Thesis, Bandung, Indonesia: Institut Teknologi Bandung press.

Patmosukismo, S., \& Yahya, I. (1974).The basement configuration of North west Java area. Proceedings Indonesia Petroleum Association. Third Annual Convention, 129-153.

Pettijhon, F. J., Potter, P. E. \& Siever, R. (1972). Sand and sandstone. New York: Springer-Verlag. http://www.mendeley.com/research/sand-and-sandstone/

Roser, B. P. \& Korsch, R. J. (1986). Determination of tectonism setting of sandstone-mudstone suites using $\mathrm{SiO}_{2}$ content and $\mathrm{K}_{2} \mathrm{O} / \mathrm{Na}_{2} \mathrm{O}$ ratio. Journal Geology, 94, 635-650. http://dx.doi.org/10.1086/629071

Satyana. A. H. \& Armandita. C. (2004). Deepwater Plays of Java: Regional Evaluation on Opportunies and $\begin{array}{lllll}\text { Risks. Proc. } & \text { Indonesian } & \text { Petroleum } & \text { Association, } & \end{array}$ http://payperview.datapages.com/data/open/offer.do?target=\%2Fipa\%2Fdata\%2F048\%2F048001\%2F 293 ipa04 80293.htm

Soeria-Atmatja, R., Maury, R. C. \& Bellon, H. (1994). Tertiary Magmatism belts in Java. Jour. of Southeast Asian Earth Sciences, 9(1/2), 3-27.

Van Bemmelen, R. W. (1949). The Geology of Indonesia, v. 1A. The Heague, Netherland: Martinus Nijhoff. http://trove.nla.gov.au/work/10504985

Zuffa, G. G. (1985). Provenance of Arenites, 148. Boston: NATO Advanced Studies Institute, Series C: Mathematical and Physical Sciences D. Reidel Publishing Company. http:/www.springer.com/earth+sciences+and+geography/geology/book/978-90-277-1944-7

Table 1. Modal averages for the turbidites of the Majalengka sub-basin West Java, Indonesia

\begin{tabular}{|c|l|l|}
\hline \multirow{2}{*}{ Strata units } & \multicolumn{2}{|c|}{ Modal values } \\
\hline \multirow{2}{*}{ Upper } & $\mathrm{Q}_{19} \mathrm{~F}_{34} \mathrm{~L}_{46}$ & $\mathrm{Qp}_{10} \mathrm{Ls}_{23} \mathrm{Lv}_{65}$ \\
\cline { 2 - 3 } & $\mathrm{Qm}_{16} \mathrm{~F}_{35} \mathrm{~L}_{47}$ & $\mathrm{Lv}_{68} \mathrm{Ls}_{24} \mathrm{Lm}_{6}$ \\
\hline \multirow{2}{*}{ Lower } & $\mathrm{Q}_{25} \mathrm{~F}_{45} \mathrm{~L}_{29}$ & $\mathrm{Qp}_{18} \mathrm{Ls}_{29} \mathrm{Lv}_{52}$ \\
\cline { 2 - 3 } & $\mathrm{Qm}_{21} \mathrm{~F}_{47} \mathrm{~L}_{30}$ & $\mathrm{Lv}_{57} \mathrm{Ls}_{32} \mathrm{Lm}_{9}$ \\
\hline
\end{tabular}


Table 2. X-ray fluorescence chemical analysis of the turbidite from the Majalengka sub-basin

\begin{tabular}{|c|c|c|c|c|c|c|c|c|c|c|c|c|c|}
\hline No & terval & ID & $\overline{\mathrm{SiO}_{2}}$ & $\mathrm{TiO}_{2}$ & $\mathrm{Al}_{2} \mathrm{O}_{3}$ & $\mathrm{FeO}$ & $\mathrm{MnO}$ & $\mathrm{MgO}$ & $\mathrm{CaO}$ & $\mathrm{Na}_{2} \mathrm{O}$ & $\mathrm{K}_{2} \mathrm{O}$ & $\mathrm{P}_{2} \mathrm{O}_{5}$ & $\mathrm{H}_{2} \mathrm{O}$ \\
\hline 1 & pper & R-47 & .8 & 1.03 & 11.36 & 72 & .33 & 6 & 5.49 & 0.96 & 44 & 17 & 8.91 \\
\hline 2 & & & & 52 & 40 & 24 & .3 & (111 & $2=0$ & 0.57 & 75 & .07 & 1.74 \\
\hline 3 & & & & 53 & .86 & 0.48 & 56 & 13 & 75 & .9 & 38 & .21 & .74 \\
\hline 4 & per & & 71 & 95 & .09 & .85 & 41 & 31 & 8.33 & .98 & .45 & .18 & 1.32 \\
\hline 5 & per & & 3.71 & 95 & 1.09 & 85 & 41 & 21 & 8.33 & 0.98 & 0.45 & 0.18 & 11.32 \\
\hline 6 & & & 84 & & 612 & 7 & 018 & 50 & 753 & 21 & 94 & .17 & 95 \\
\hline 7 & & & & & & & & & $=70$ & 205 & 135 & .19 & 17 \\
\hline 8 & & & & & & & 0.14 & & .74 & $=$ & .48 & 11 & 4.57 \\
\hline 9 & & & .35 & 1.08 & 13.3 & 10.36 & 0.17 & 14.91 & 4.8 & 1.49 & 0.31 & 0.11 & 10.9 \\
\hline 10 & oper & 48 & .42 & 0.79 & 17.82 & 5.28 & 0.15 & 2.83 & 10.1 & 1.1 & 1.19 & 0.13 & 7.65 \\
\hline 11 & Upper & B-6 & 2.57 & 1.02 & 14.79 & 9.34 & 0.12 & 10.29 & 5.27 & 1.7 & 0.31 & 0.1 & 4.33 \\
\hline 12 & pper & -9 & .77 & 1.31 & 15.5 & 10.27 & 0.23 & 9.69 & 9.4 & 1.97 & 0.19 & 0.26 & 6.19 \\
\hline 13 & ower & & 7.36 & 1 & .73 & 8.74 & 0.19 & 4.5 & 5.99 & 2.25 & 0.53 & 0.18 & 5.41 \\
\hline 14 & Lower & & 206 & 08 & 45 & 30 & 0.09 & 2.86 & 17.75 & .69 & 1.56 & 0.05 & 14.52 \\
\hline 15 & - & & & 107 & $=26$ & & 0.15 & 507 & 00 & 100 & 0.32 & 0.13 & 7.67 \\
\hline 16 & & & & & & & & & & 110 & 0.54 & .13 & 4 \\
\hline 17 & & & & & & & & & & 10 & 34 & .17 & .47 \\
\hline 18 & & & & & & & & & & .83 & 24 & .18 & 62 \\
\hline 19 & & & & & .52 & & 0.44 & & & & 21 & 0.14 & 11 \\
\hline 20 & & & & 85 & 81 & & 0.08 & & 27 & .1 & 32 & 0.13 & 85 \\
\hline 21 & & & & & 31 & 50 & 022 & & 16 & 77 & 34 & 2 & 79 \\
\hline 22 & Lower & $\mathrm{SD}$ & 46.12 & 0.9 & 2 & 043 & 0.74 & 2.66 & 7.25 & 2.98 & 48 & 01 & \\
\hline 23 & $T=$ & 7 & & 1 & 1544 & 602 & 022 & 3.76 & 11 & 20 & 0.74 & 0.11 & 8.65 \\
\hline 24 & & & & & 17.98 & & 0.11 & & & 217 & J & 0.21 & 4 \\
\hline 25 & & & & & & & & & & 2.93 & 0.93 & 0.24 & 3.55 \\
\hline 26 & wer & -5 & & 1.05 & 15.21 & 8. & 0.15 & 10.59 & 8.94 & 2.12 & 0.16 & 0.12 & 6.57 \\
\hline 27 & Lower & $1-2$ & .79 & 0.61 & 12.38 & 2.76 & 0.03 & 1.26 & 1.45 & 5.12 & 0.21 & 0.06 & 2.1 \\
\hline 28 & Lower & T-7 & .83 & 1.03 & 17.44 & 10.48 & 0.27 & 5.34 & 10.76 & 2.03 & 0.41 & 0.24 & 0.01 \\
\hline 29 & Lower & T-4 & .36 & 0.85 & 17.94 & 7.87 & 0.07 & 4.96 & 2.64 & 2.89 & 0.99 & 0.06 & 4.16 \\
\hline 30 & I ower & LT-3 & 5036 & 1.08 & 15.58 & 9.42 & 0.11 & 8.92 & 7.24 & 1.91 & 03 & 0.27 & 4.63 \\
\hline 31 & 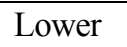 & $4 T 6$ & 156 & 100 & 1 & 101 & 0.13 & 10 & 5 & .86 & 0.28 & 0.11 & 32 \\
\hline 32 & ower & 101 & nis & 0.65 & 12.55 & 3.2 & 0.08 & 28 & 15.51 & 2.71 & 1.49 & 0.05 & 20.62 \\
\hline 33 & 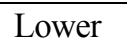 & NB-3 & 200 & 116 & 15.48 & 11 & 018 & 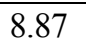 & 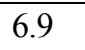 & 200 & 0.27 & 0.26 & 5.15 \\
\hline 3 & wer & JB 2 & .35 & 67 & 12.4 & .1 & 0.04 & 1.6 & 1. & 4.88 & 0.24 & 0.08 & 1.66 \\
\hline
\end{tabular}




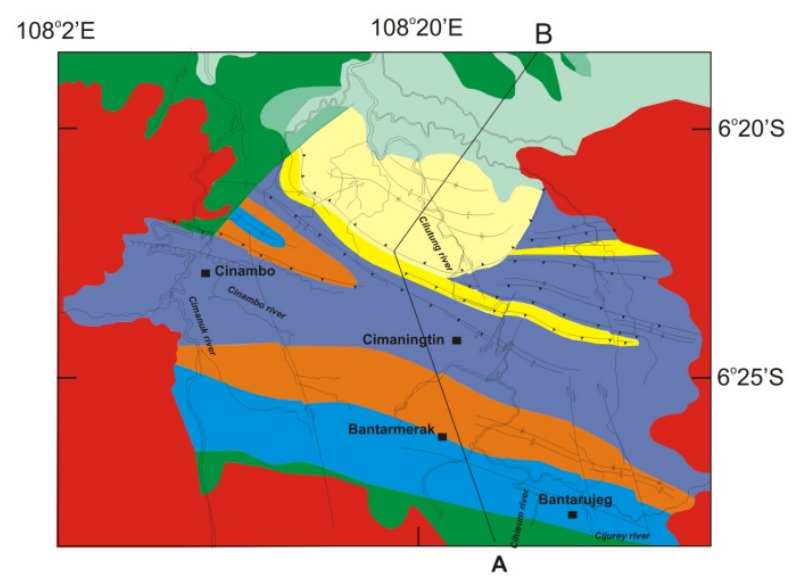

GEOLOGY MAP OF MAJALENGKA AREA WEST JAVA, INDONESIA
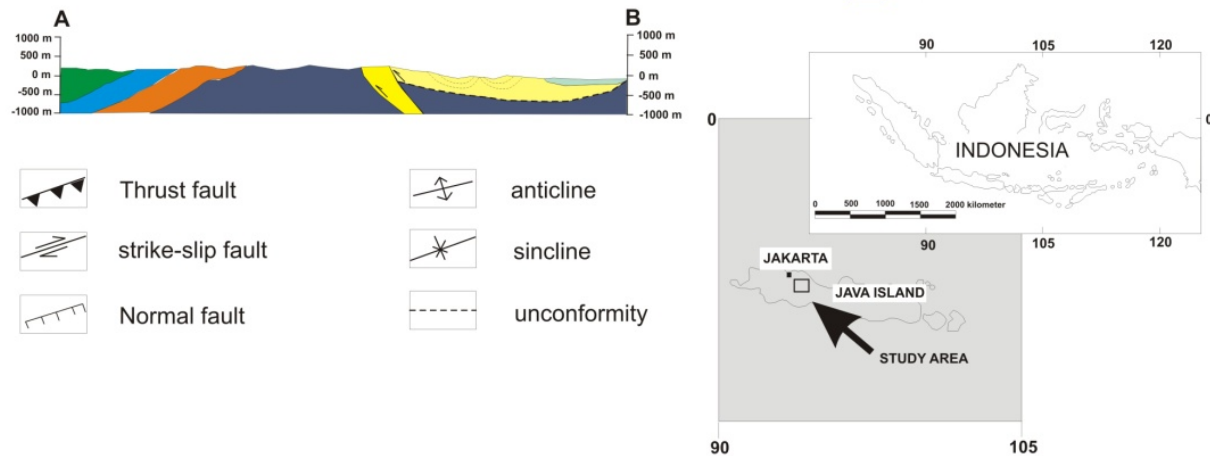

Figure 1. The geology map of Majalengka sub-basin (left picture) and the location of study area (right picture)

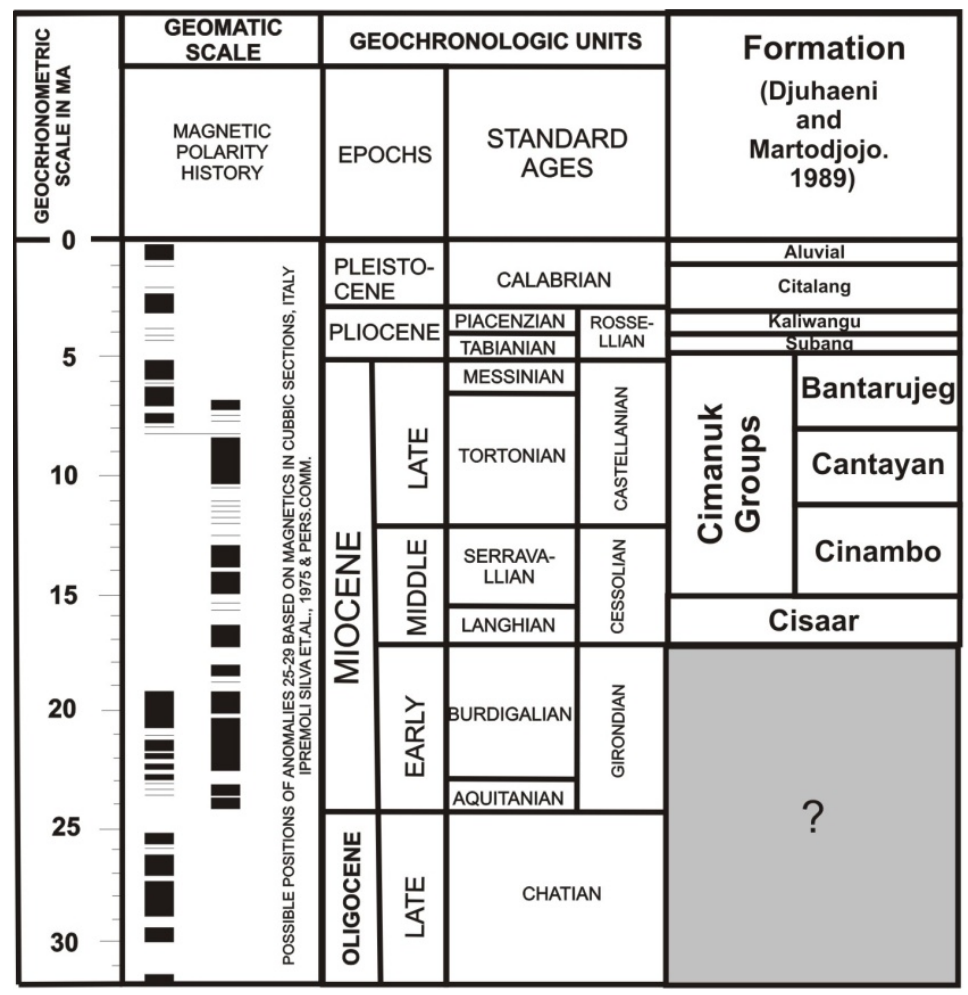

Figure 2. Geologic time chart showing the relation of age relative of the rock unit in the Majalengka sub-basin (modified from Djuhaeni and Martodjojo. 1989) 

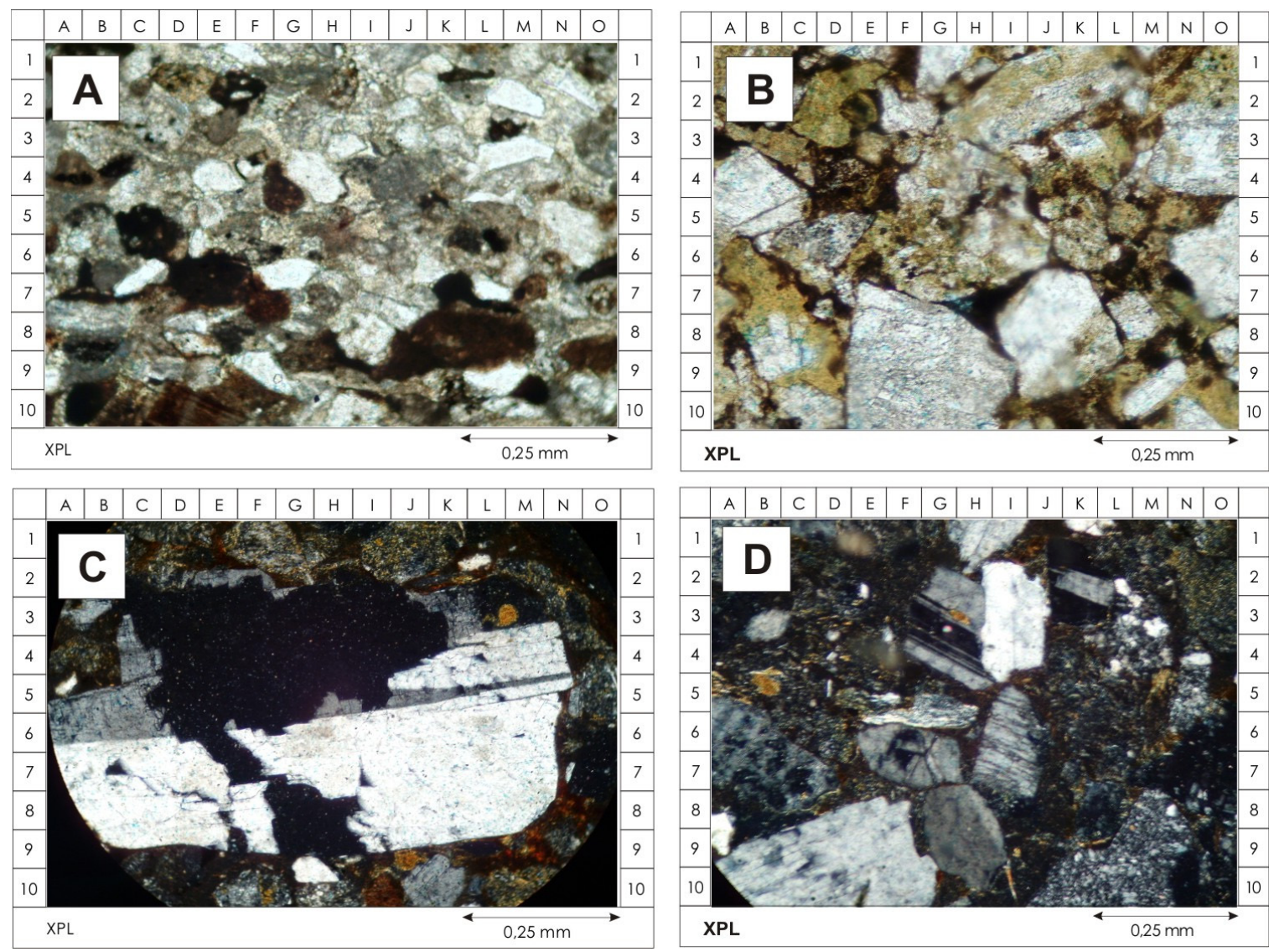

Figure 3. Photomicrographs of selected sandstone samples of the turbidite-sequence at the Majalengka sub-basin. (A). General view showing sub-rounded to sub-angular grains of the quartz and plagioclase. (B). Lithic fragment showing very coarse grains. (C and D). General view showing the very coarse grain of the plagioclase. Most samples are in cross-polarized light. Scale bar are $0.25 \mathrm{~mm}$ 

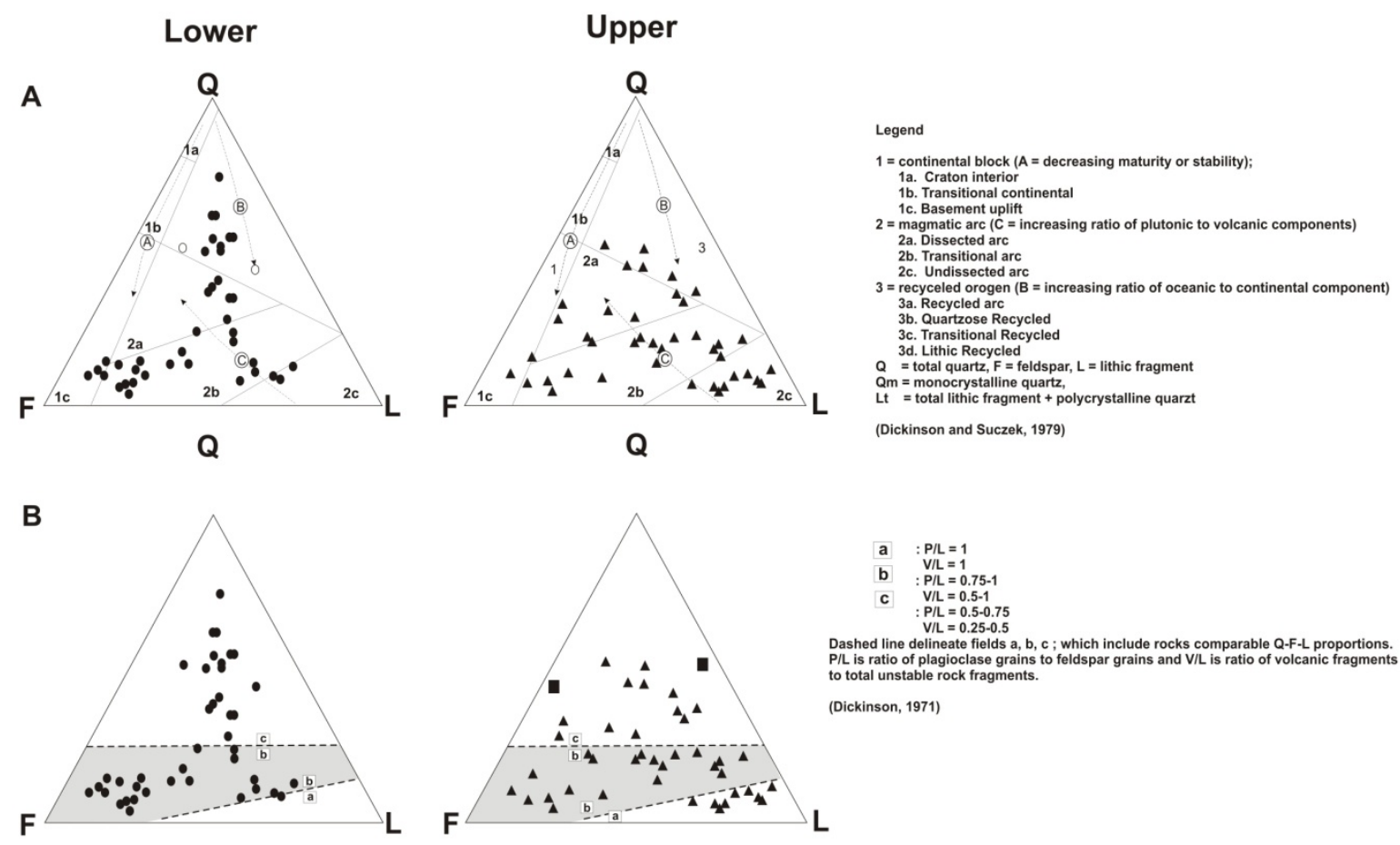

Dashed line delineate fields $\mathrm{a}, \mathrm{b}, \mathrm{c}$; which include rocks comparable Q-F-L proportions. to total unstable rock fragments to feldspar grains and V/L is ratio of volcanic fragments (Dickinson, 1971)

C
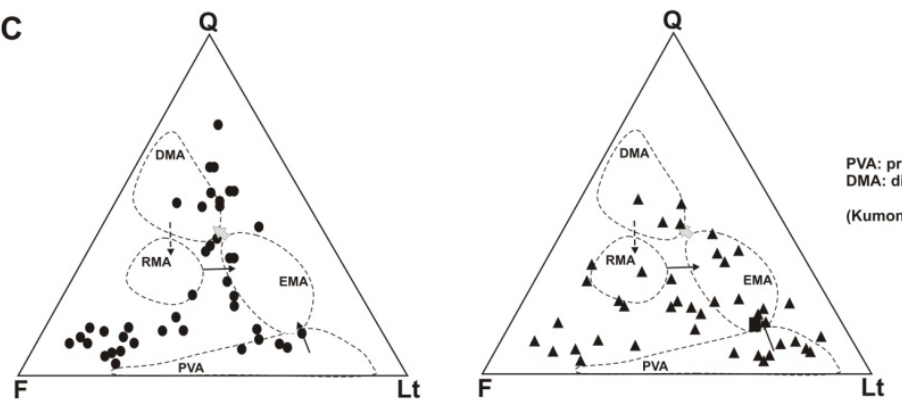

Figure 4. Sandstone modal data plotted on a QFL diagrams after Dickinson and Suczek, 1979 (A); Dickinson, 1971(B); Kumon and Kiminami, 1994 (C) 
a

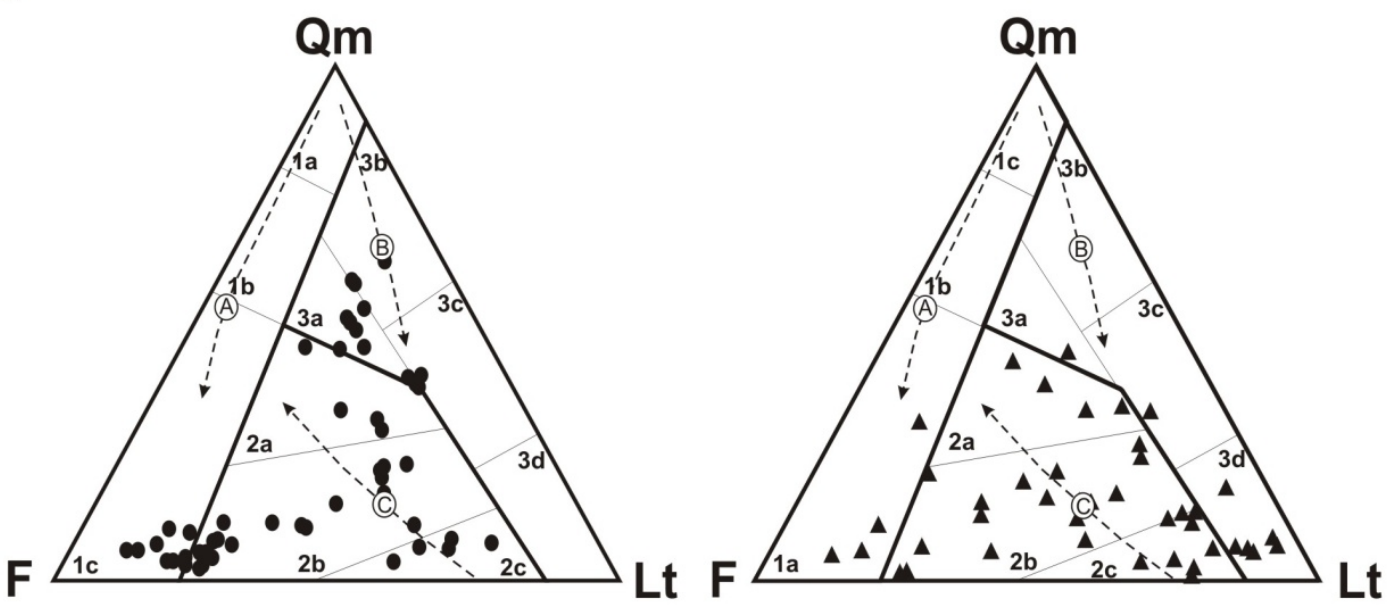

Legend
$1=$ continental block $(A=$ decreasing maturity or stability $)$;

1a. Basement uplift

1b. Transitional continental

1c. Craton interior

$2=$ magmatic arc $(C=$ increasing ratio of plutonic to volcanic components $)$

2a. Dissected arc

2b. Transitional arc

2c. Undissected arc

$3=$ recyceled orogen $(B=$ increasing ratio of oceanic to continental component $)$

3a. Recycled arc

3b. Quartzose Recycled

3c. Transitional Recycled

3d. Lithic Recycled

$Q$ = total quartz, $F=$ feldspar, $L=$ lithic fragment

Qm = monocrystalline quartz,

$\mathrm{Lt}=$ total lithic fragment + polycrystalline quarzt

cycle $=$ Lower (equivalent with Cinambo Formation)

triangular $=$ Upper (equivalent with Halang Formation)

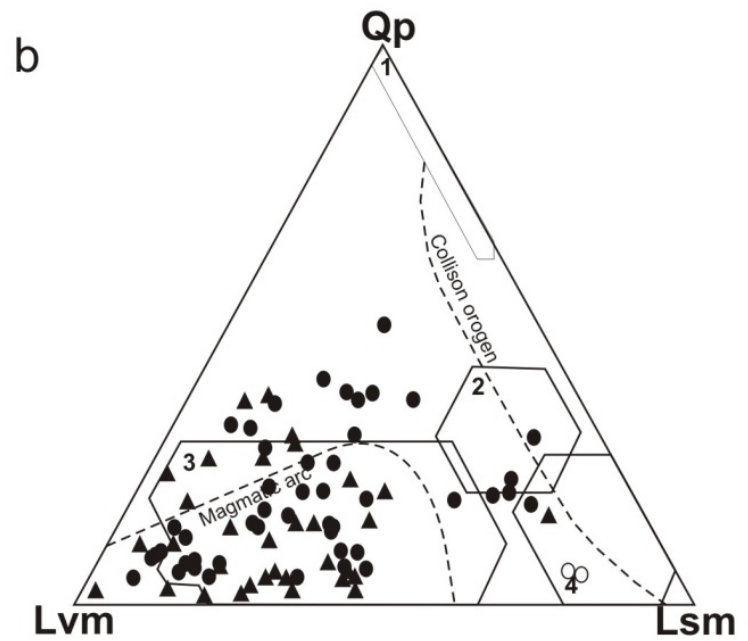

1. Rifted continental margin

2. Subduction complex and magmatic arc

3. Mixed magmatic arc and rifted continental margin

4. Suture belt

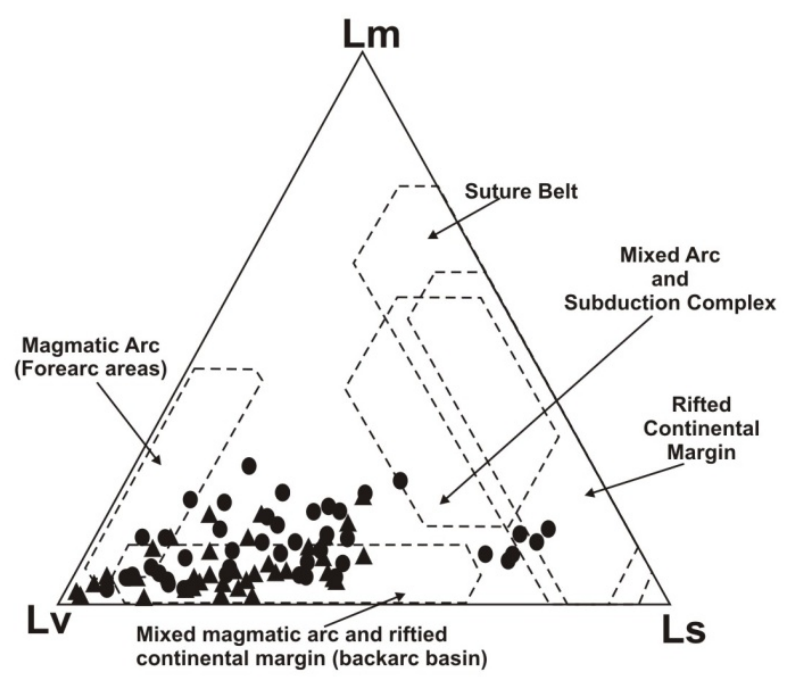

Figure 5. (a). Sandstone modal data plotted on a QmFLt diagrams after Ingersoll and Suczek ,1979. (b). Sandstone modal data plotted on a QpLvLs and LmLvLs diagrams after Dickonson, 1971; Dickinson and Suczek, 1979 


\section{a}

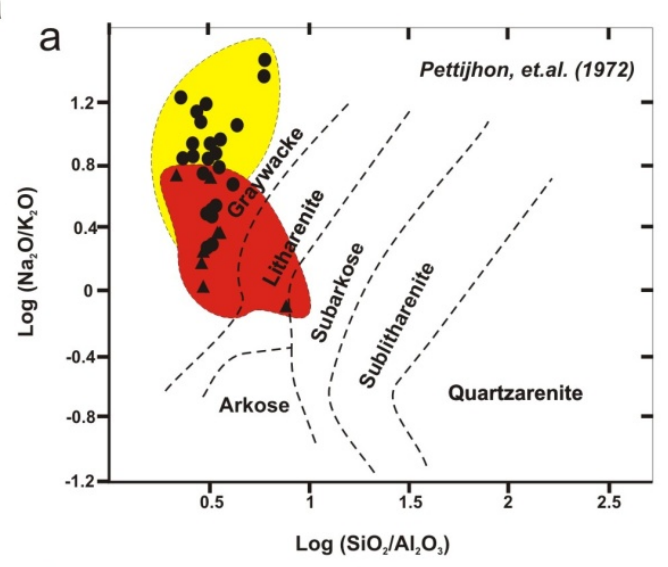

C

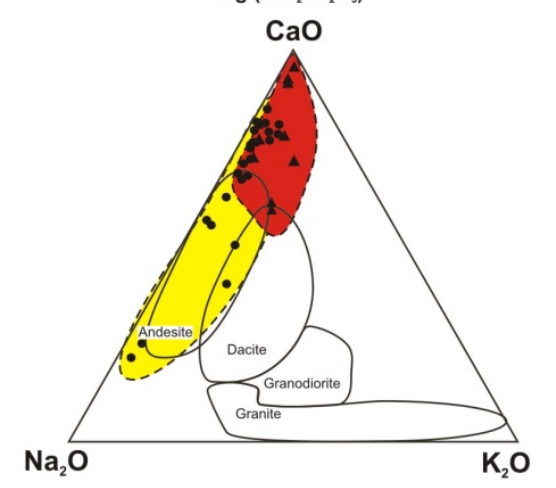

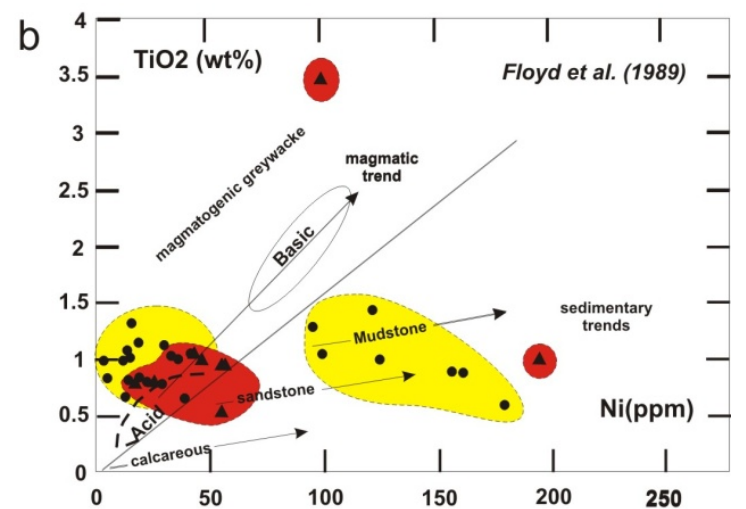

d

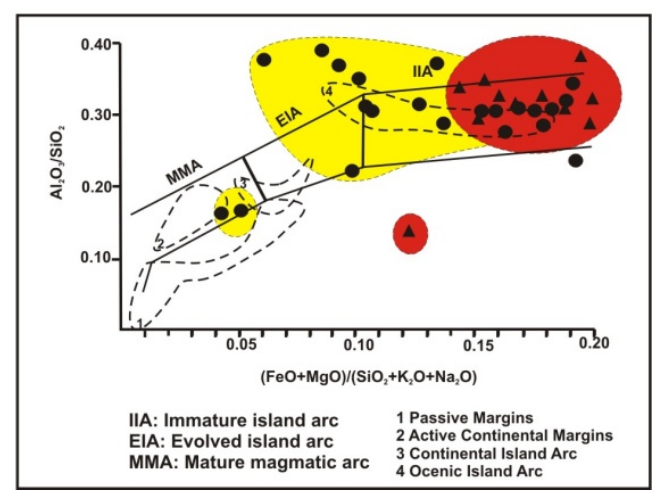

Figure 6. (a). Geochemical characteristics of turbidite of the Majalengka sub-basin (Pettijhon et al. 1972). (b). $\mathrm{TiO}_{2}$ versus Ni plot for turbidite from Majalengka sub-basin. Acidic and basic fields after Floyd et al. (1989). (c). Triangular diagrams (CaO-Na2O-K2O) plotted for turbidite of the Majalengka sub-basin. Various suites was represented by using dotes lines mark. The average of several volcanic rocks such as (A) andesite, (D) dacite, (Gr) granodiorite, and (G) granite after Le Maitre (1976). The cycle symbol's is the lower part, while the triangular is the upper part. (d). The discrimination diagrams for provenance of turbidite (Kumon and Kiminami, 1994) 

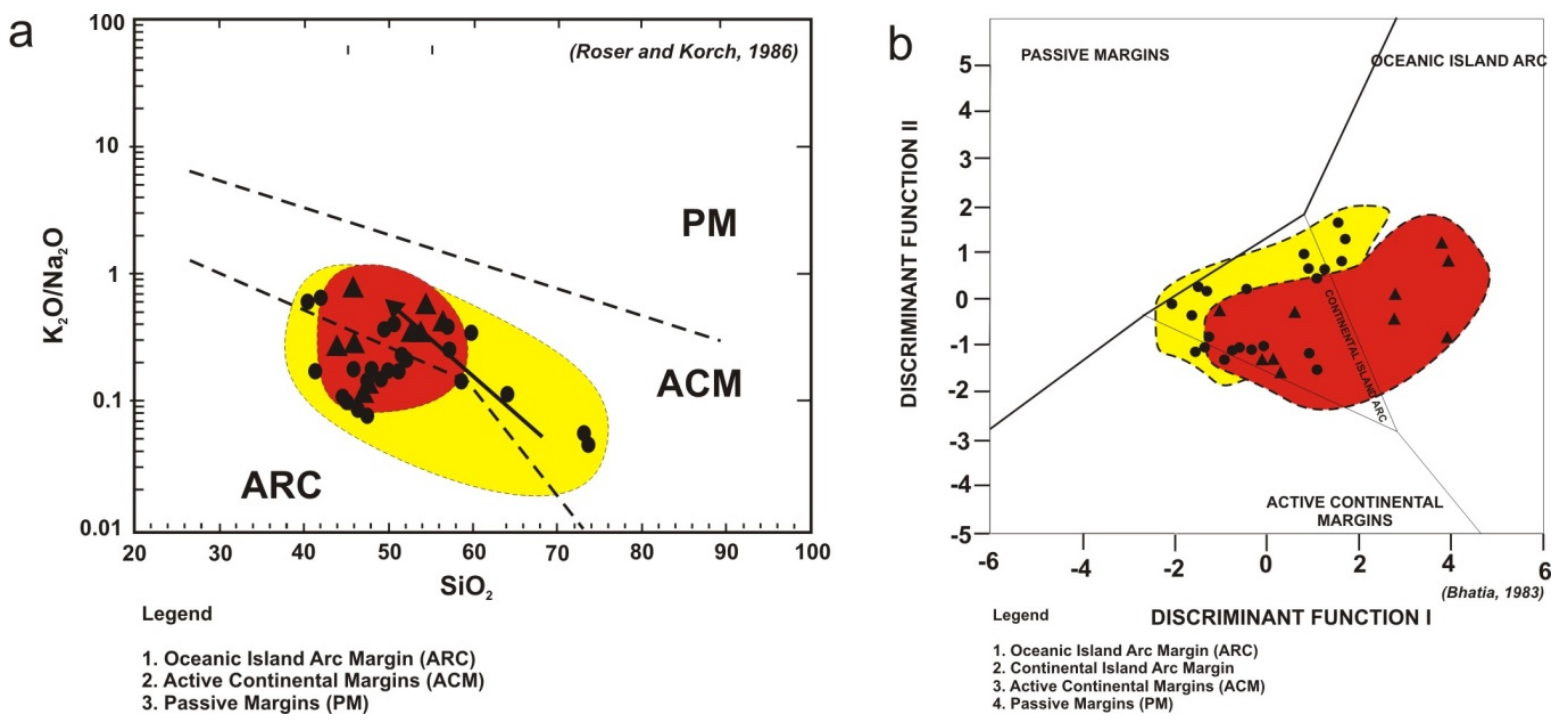

Figure 7. (a). Tectonism discrimination diagram for turbidite from the Majalengka sub-basin (after Roser and Korsch, 1986). (b). Discrimination function analysis classification plot of the turbidite of Majalengka sub-basin (Bhatia, 1983). Both diagrams ( $a$ and $b$ ) show that there are no indication of the sediment source derived from the passive margin

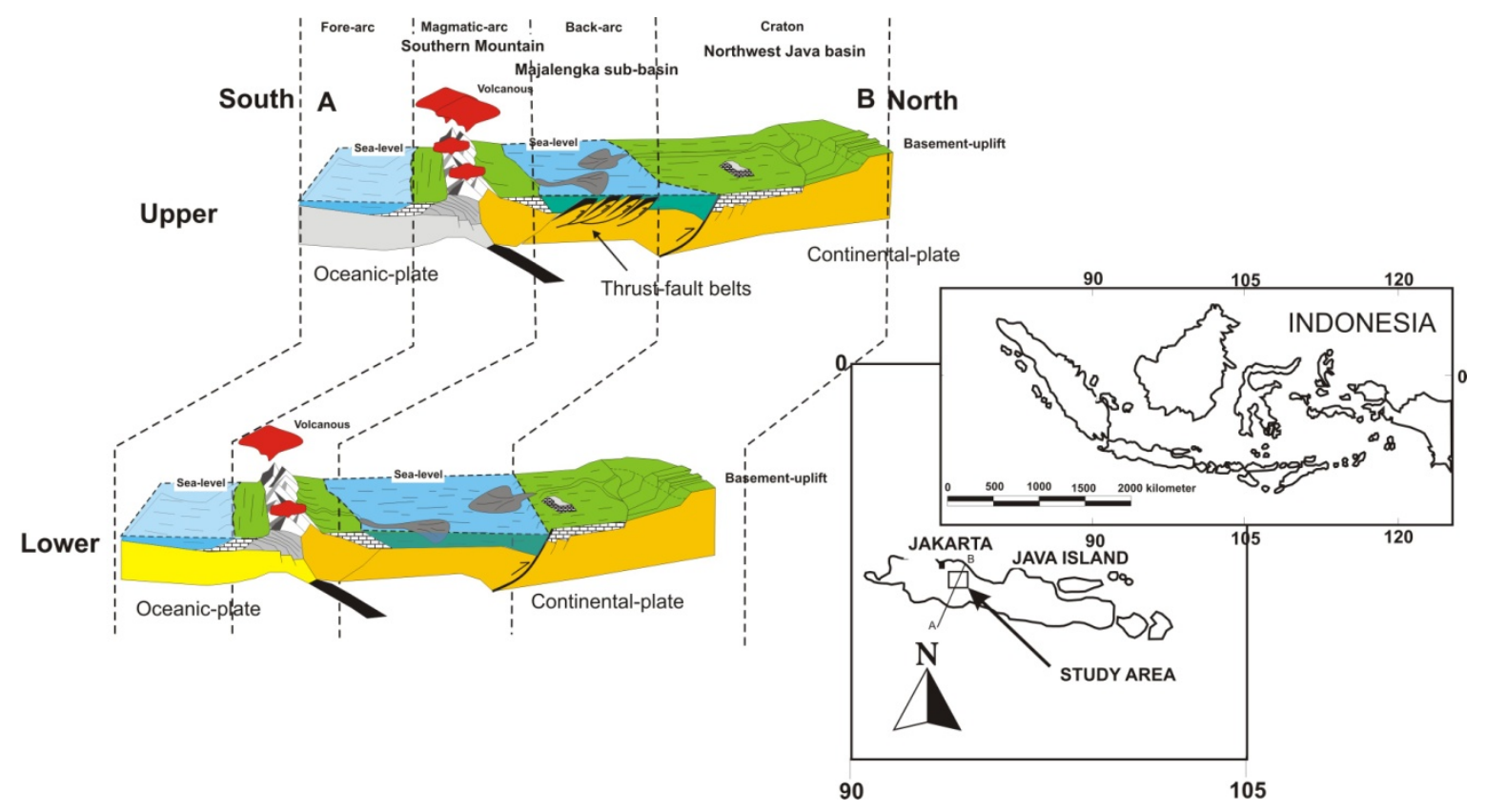

Figure 8. The cartoon of the basin-forming of the Majalengka sub-basin during the middle to late Miocene. Lower part is the middle Miocene, while the upper part is the late Miocene 